\title{
A 'tröstlich pictura': Luther's Attitude in the Question of Images*
}

\author{
ROSEMARIE BERGMANN
}

Art historians often attribute to Protestantism the decline of the visual arts after the first third of the 16th century in German speaking countries. It is pointed out that Gruenewald, clearly in sympathy with Protestantism, ceased to paint in his final years, supposedly fearful of Catholic persecution. Holbein, a reluctant follower of the new creed, is said to have emigrated to England in protest against Swiss iconoclasm. ${ }^{1}$ Such statements are generalizing half-truths and might be countered by mentioning Hans Baldung whose career continued to blossom in Strasbourg or the elder Lucas Cranach who painted, in 1552, thirty-two pictures of which thirteen were of religious subject matter. ${ }^{2}$ It is also worth remembering that the Catholic Rhineland, Bavaria, Austria and Silesia suffered a similar decline in artistic production. The stimulus provided by the Tridentinum for religious art led to an immediate efflorescence in Italy and Spain with the Southern Netherlands following slightly later, but its effects on Germany are not manifest before the 18th century. Thus, the claim that Protestantism was the greatest detriment to the thriving of the representational arts there must be viewed with caution, especially when the relationship is simplistically regarded as one of cause-and-effect. ${ }^{3}$ While it is undeniable that the Reformation is a codeterminant in the decline of German art, the social, economic and political conditions that are responsible for the general malaise of the century and the resulting Thirty Years' War contributed far more to the strangling of artistic productivity. For a clearer understanding of the role of the Reformation vis-à-vis the visual arts one has to look at the attitudes of its key promoters, specifically Luther.

From the available evidence it can be confidently said that Protestants rarely objected in principle to the presence of art in religious life - the flowering of graphic arts and church music, much promoted by both Zwingli and Luther, indicates that much. Also, the prohibitive and des-

* An earlier verison of this paper was delivered at the annual meeting of the Canadian Society for Renaissance Studies/Societe Canadienne d'Etudes de la Renaissance on May 2, 1979, at the University of Saskatchewan at Saskatoon. 
tructive effects of reforming zeal and radicalism remained quite limited in Germany. The white-washed imageless interior of the Reformation church in Germany is more fable than fact. Pre-Reformation Gothic altarpieces continued to be used in Protestant churches, although sometimes their iconography was slightly adapted, their position changed in keeping with the new doctrine. ${ }^{4}$ It seems obvious that the Lutheran church was far more lenient with pictures than the Reformed churches, considering the far more radical attitudes of the Swiss and Netherlandish Reformers. Yet, even in some relatively recent pronouncements on the problem, Luther remains the enemy of images. Ruestow perpetuates this view, and it is downright puzzling to note that he uses the well-known Erasmian phrase of the "Lutherana Tragoedia Artis" out of context as title for his controversial article. ${ }^{5}$ The fact is that, notwithstanding all their intellectual and spiritual differences, both men show considerable agreement in the image question. In a letter to John Vegara of $24 \mathrm{March}$, 1529 , Erasmus gives vent to criticism of the radical "idolomachy," and in De amabile Ecclesiae concordia he speaks of the usefulness of religious art:

...this silent poetry (i.e. sculpture and painting) can at times have a stronger effect on human emotions than a man, even an eloquent one, could ever achieve by words. If only all the walls in all the churches were to show the life of Christ in a becoming fashion. ${ }^{6}$

And in Luther's Wider die himmlischen Propheten, von den Bildern und Sakramenten, the key treatise stating his personal and theological views on the iconoclastic activities of the Karlstadt group, one reads the following:

I wish to God, I could persuade the lords and the rich to have the whole Bible painted inside and out on their houses for everyone to see; that would be a Christian deed. I am also certain that God wants one to hear and read his works, above all the sufferings of Christ. But if I hear and think about it, I find it impossible not to form an image of it in my heart. ${ }^{7}$

Equally similar are both men's thoughts on the veneration and cult of images in the churches, which is the stand taken by most humanists. ${ }^{8}$

Zwingli too inveighed against the rampant misuse of images in the Catholic church, but not before, it seems, the 1523 talks on images and the Mass, whereas Luther's first pronouncements date back to 1518 . Zwingli had then decided that none must be retained in the churches and he never changed his mind on this point, not even in the light of the most radical manifestations of Bildersturm in Zürich and Basel. Most of his thoughts on the image question - and they are rather rigid and unchanging - are found in De vera et falsa religione of $1525 . .^{\circ}$ Although he is clearly more on the side of the Bilderstürmer than that of the 
Bilderschirmer, he does speak against all rash and revolutionary activities. First, the true faith and the contemptibility of so-called holy images have to be preached; only then should they be removed and in an orderly fashion prescribed by the civic authorities. Also, he deems it "blameworthy nonsense" to condemn and destroy all images without distinction. There are, after all, subjects that are represented "in Geschichtswyss." that is historically, which should not arouse people to honour them inordinately. However, given the nature of man, he is always in danger of worshipping an image placed in the house of worship (a statue of Charlemagne in the market place is fine, but when in a church, it should be destroyed). So, to prevent the sin of idolatry, it is best to remove the images, as one would prevent the boys from sitting around with the girls too long. From a somewhat narrow moral point of view, Zwingli also objects to whorish depictions of Mary Magdalen, to the Virgin Mary painted with bared breast, to naked Sebastians and the like. Theologically, he defends the complete prohibition of images by referring not only to the first and second Commandments (which, it was argued by others, were law to the Jews and not to Christians) but also to numerous passages in the New Testament.

In October 1524, after he had been expelled from Wittenberg, Andreas Bodenstein of Karlstadt visited Strasbourg to confer with the reformers there. They subsequently wrote to Zwingli and Luther, asking both men for guidance on the sacrament of the Last Supper, infant baptism and the use of images in worship. Zwingli's answer, addressed to Bucer, argues earnestly against images in the house of God, for they appeal solely to the senses ("solum sensum moveant") and take man away from God. Only the word can reveal the essence of God, and he is afraid that "quantum sensui tribueris, tantum spiritui detraxeris." 10 Luther puts more trust in human nature than Zwingli in his answer contained in the Letter to the Christians at Strasbourg in Opposition to the Fanatic Spirit: "Paul says (1 Cor. 8:4), "We know that "an idol has no real existence." 'If so, why then should the Christian conscience be ensnared and tortured on account of something that has no reality?"11 And, if man is taught that worship of images is $\sin$, "He will have pictures painted on the walls only because he likes them or for decoration or some other reason that does not involve sin." 12

Although both Reformers share much in their opposition to the institutionalized abuse of images, Luther already partially defends them before Zwingli first mentions them, challenged by Karlstadt's and his followers' iconoclastic activities in Wittenberg. ${ }^{13}$ In answer to them Luther wrote the Eight Sermons at Wittenberg (dating to 1522) and the already quoted polemic treatise Against the Heavenly Prophets in the Matter of Images and Sacraments, 1525. ${ }^{14}$ These two works are the 


\section{8 / Renaissance and Reformation}

central documents for the examination of his attitude in the controversy over the images and most of the following quotations refer to them. Dispersed statements on the subject also appear in the Letters, Sermons, the Large Catechism, the Magnificat and the Tischreden. Already in the Decem praecepta of 1518 and in some early sermons Luther declares himself vehemently against belief in the healing powers of relics and saints in Churches, and compares it to the sinful veneration of idols in the Old Testament. ${ }^{15}$ Yet, neither the issues raised by Jewish idolatry nor those of the Byzantine iconoclastic controversy seem to concern him very much. Indeed, he trusts that - at least in Wittenberg people are sufficiently educated in the true faith not to take the Crucifixus for the Lord, not to worship wood and stone. ${ }^{16}$ The real danger in Luther's eyes is the Catholics' illusionary notion that the presentation of altarpieces and statues, the foundation of churches, will secure favours from God or even salvation. This erroneous Heilsglaube of which the papists are full, he says, constitutes the most deplorable abuse of images, an abuse from which princes and high church officials are not exempt: "Do you think the Duke Frederick (III, the Wise, Elector of Saxony), the bishop of Halle (Albrecht of Hohenzollern, archbishop of Mainz and Magdeburg) and others would have dragged so many silver images into the churches, if they thought it counted for nothing before God?"17 Incidentally, Luther's valid and courageous criticism of his greatest benefactor and protector, the Elector of Saxony, could be extended to include the Duke's belief in the power of the saints. One piece of evidence for this is the well-known Dresden Altarpiece by Dürer, the wings of which (c.1504) represent Saints Sebastian and Anthony, whose apotropaeic powers Frederick sought in his phobic fear of the plague. ${ }^{18}$ In sum, the abusive act is image presentation with the hope of rendering service to God and/or seeking absolution from wrongdoing, which, of course, parallels the purchase of indulgences and is totally incompatible with their justification theology.

There is another group of images that Luther does want to see abolished because he considers them blasphemous. Examples are: The Virgin Mary as Mater mediatrix between man and Christ in representations of the Last Judgment, Mary nourishing a kneeling donor with milk spurting from her breast, bleeding crucifixes and other "coarse nonsense." 19 "To ensnare the conscience with laws in this matter is death for the soul." 20 In the light of Luther's justification by faith alone such images are idolatrous and therefore intolerable.

However - and here Luther differs markedly and emphatically from Zwingli and most other reformers - the abuse of images should not annihilate their use; wherefore a law to remove all of them from the houses of God is wrong. Further, by making laws against images, the 
enemies of images forbid what God has not forbidden. And in diminishing the freedom of Christians by such prohibitive measures the image breakers are no better than the Pope. Religious images per se, he says in the Eight Sermons at Wittenberg, "are neither here nor there, neither evil nor good." There may be people who hold no wrong opinion of them and to whom they may be useful. Besides "we must not condemn anything because it is abused.... there are many people who worship the sun and the stars. Therefore we propose to rush in and pull the sun and the stars from the skies. No, we had better let it be. Again, wine and women bring many a man to misery and make a fool of him; so we kill all the women and pour out all the wine.... Indeed, if we want to drive away our worst enemy. . . we shall have to kill ourselves, for we have no greater enemy than our own heart." 21 But man is born with heart and senses, and if those are attached to images in ignorance, Luther writes to Leopold zu Stolberg, ${ }^{22}$ it will not do to remove the objects from their view. Rather one must educate their hearts to the true faith through the unadultered word of God. And again he writes, "I approached the task of destroying images by first tearing them out of the hearts through God's word.... For when they are no longer in the heart, they can do no harm when seen with the eyes.... Images for memorial and witness such as crucifixes and images of saints are to be tolerated." 23

The treatise Against the Heavenly Prophets (from which this last quotation is taken) reaffirms what is said in the Invocavit sermons. Only Luther's attitude to the images now changes from a merely defensive to a strongly apologetic one. And in his persuasive justification of the permissibility of, and even the right to images, he speaks as theologian, compassionate pastor, pedagogue and concerned human being, all in one. He repeatedly urges tolerance with the weak who might use images wrongly, with the simple folk who, like children, cannot be taught by word alone but need Merkbilder. In recognition of the pedagogical value of the representational arts he endorses the principle of the Thomistic formula of their threefold function. Especially useful are "images and pictures taken from the Scriptures and from good histories." 24 In this connection Luther's keen interest in Bible illustration should not go unmentioned - those in his own translations make for interesting study! He seems to have dreamed of a 'reformed' biblia rudium; he even made sketches for the kind of illustration he envisioned according to the testimony of the corrector from the Lufft publishing house that printed Luther's Bible translations. ${ }^{25}$ His insistence was on simple, correct illustration of the text, the elimination of all symbolic and extraneous matter. It should not surprise that, in line with Protestant dogma, his criticism was particularly directed against the traditional depiction of the Last Judgment: Mary was not to appear as intercessor, Christ should not be 
shown as the fierce judge, there should be no emphasis on his wounds. Also, the devil in the guise of an unnatural monster would be far less instructive than his image as a fallen man. ${ }^{26}$ Clearly, Luther views book illustration as being in the service of evangelization.

When considering Luther's attitude toward images one must not overlook his natural inclination toward the pictorial. It is part of his genius that he was an "Augen- und Ohrenmensch," says Heinrich Bornkamm, drawing attention to his highly developed acoustic and visual sense, both of which render his writing style so eminently perceptual and vivid, just as they make him appreciate the pictorial quality of biblical language. ${ }^{27}$

Now there are a great many pictures (painted by words) in those books, both of God, the angels, man and animals. . . Pictures contained in these books we would paint on walls for the sake of remembrance and better understanding since they do no more harm on walls than in books.

The following example may stand for the richness and forcefulness of visual images in his own style.

For whether I will or not, when I hear of Christ, an image of a man hanging on the cross takes form in my heart, just as the reflection of my face naturally appears in the water when I look into it. If it is not a sin but good to have an image of Christ in my heart, why should it be a sin to have it in my eyes? ${ }^{28}$

But in Luther's perception hearing and seeing complement and mutually reinforce each other. When he beholds an image of the Crucified, it seems to want to say to him 'venite ad me omnes.' In one of the Tischreden of 1532 he remarks, pointing to a Madonna picture on the wall, "The baby Jesus sleeps in the arm of His mother. Once woken up, he will surely ask us what we did and how we lived." ${ }^{29}$ Of course, the Word is of prime importance in Luther's revelation theology, but image and 'sign' are also inextricably bound up with it. He knows that the Word can never be experienced and understood without the engagement of the senses, for "we are only poor creatures and therefore need (and make in our minds) images for comprehension." However, instead of fighting human nature as Zwingli and other reformers do, he draws different conclusions. With his characteristic, profound love for God's creation Luther argues that human nature is God-given and as such cannot be sin. Moreover, God came to man through Christ and revealed himself in the concrete world of the senses in order that "we should not complain, we could not find him." Thus, it must be considered as ordained by God that "ears should not hear alone but also see with eyes." 30 The implication in this phrase from a sermon is - it hardly needs mentioning Luther's lifelong tenet that in the learning of God's truth the eye is the servant of the ear, the image the handmaiden of the word. These 
thoughts, although partly based on the Byzantine defence of images, are unique to Luther's theology and perhaps the most important point in his justification of religious images.

From this cursory examination of statements on images in Luther's works, a number of observations emerge. 1. Among the spokesmen of the Protestant Reformation he displays the most positive attitude towards religious art. His only serious reservation is the donation of images with the aim of winning favour before God. This is a point that had not been made by earlier critics of images. 2. While Zwingli and Calvin are pessimistic and afraid of the misuse of images Luther - concurrent with the growing consolidation of his Reformation theology - becomes more optimistic and confident that man's education to the true faith through the Word can be furthered and supported by images, provided they are of an evangelical character. This psychological approach to the problem is also new.

The art historian inquiring into Luther's attitude toward the visual arts must next ask the question: Has Luther had a tangible and specific impact on the representational arts; in other words, has the reformer reformed the images? I believe the answer to be in the affirmative. In the first place Luther is, of course, a party to the Reformation crusade against cult images, the Ölgötzen or idols in oil, as Karlstadt calls them in his treatise Von Abthun der Bilder of 1522. We heard before of Luther's objection to bleeding crucifixes and certain images of the Virgin Mary. This meant naturally the demise of a whole range of religious subject matter and its restriction to christological and eschatological themes, in the churches at least. Yet, where most reformers condemn all mariological representations, Luther does not. In a most interesting passage from the Magnificat of $1521,{ }^{31}$ he suggests practically how to depict the "blessed Virgin" by saying that portraying her as a lofty, beautiful Queen of Heaven in whom nothing despicable can be found would contrast her with us instead of with God, and thus "deprive us of her example" as the humble, lowly and self-effacing mother of the Lord. Northern painters have heeded the message ever since by depicting her patently unbeautiful. In this case Luther was instrumental in modifying traditional iconography. When Dürer in his latest woodcut of the Last Supper (fig. 1) replaces the paschal Lamb with an over-size chalice and adds an equally prominent paten to the composition, the change is clearly due to Luther's explanation of the Holy Mass not as a sacrifice but as a sacramental promise of Redemption. More indirectly, his influence can be seen in the introduction of hitherto neglected iconographical subject matter such as Christ Blessing the Children, ${ }^{32}$ which most certainly results from the controversy over infant baptism. One might also think of his Taufbüchlein, 1526. Themes like Christ and the Adul- 


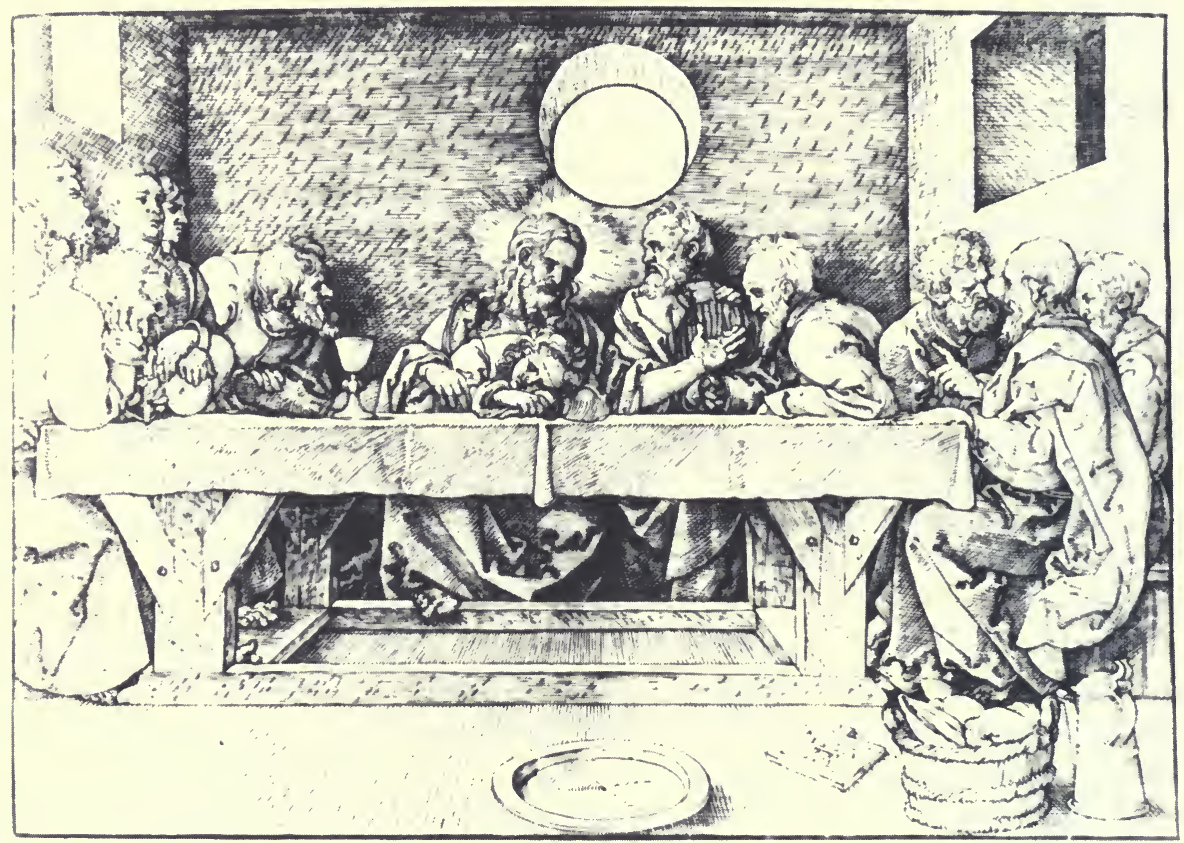

Fig. I A. Durer, Last Supper, woodcut, I 523, London, British Museum

teress, Christ and the Samaritan Woman, and the Parables owe their sudden popularity primarily to Luther's sermons. A plethora of Old Testament subjects, particularly Moses, Job, Bathsheba and David, and Samson rending the Lion became favourites in the 1520's. They are, I believe, inspired by Luther's illustrated translation and preaching of the Old Testament.

It should not surprise one - and would in fact support my thesis of Luther's influence on the visual arts - to find all these new themes treated and frequently repeated in the atelier of the elder Lucas Cranach, Luther's intimate friend, staunch supporter, illustrator of most of his books and creator of some iconographic innovations that might be termed Lutheran. ${ }^{33}$ This is not the place to discuss the alliance between Luther's word and Cranach's images, but I would like to conclude this brief deliberation with an analysis of the didactic picture he referred to as a tröstlich pictura. ${ }^{34}$ It is a rare single woodcut dating to c.1530 (Weimar, Schlossmuseum), representing very specific ideas of Man's Fall and Redemption (fig. 2). ${ }^{35}$ In its composition Cranach employed the principle of antithesis, a time-honoured device in didactic representations, found for instance in the Biblia pauperum or, closer to our topic, in the Cranach illustrated Passional Christi und Antichristi of 1521. The design is divided 
by a tall tree, with dry branches to the left, "green" ones to the right, as indicated by the foliage. Beneath it, Moses, surrounded by Prophets, points to the Law. Further left, a naked man, fallen into sin like the first parents in the background, is pushed toward flaming hell by Death and Devil. Up above the Lord sits in Judgment with Mary and John as intercessors - one recalls that Luther declared himself against such a devotional image on theological grounds. However, here it is part of the teaching and appears on the left side, an old convention for the wrong or bad side. At the right an upright, praying man is shown the Crucified and the Lamb by John the Baptist. A stream of blood from Christ's sidewound gushes forth, propelling the dove, and flows down upon the man. In the lower right Jesus stabs death and devil as he stands on them. The mystery of the incarnation in the upper right hand corner, the Annunciation to the Shepherds and the Brazen Serpent in the background (associated with the Crucifix as prefiguration) complete the imagery.

This woodcut had been called Fall and Redemption, until at a recent Cranach-Exhibition in Basel it was given an appropriate title: The Justification of the Sinner Before the Law by the Grace of God and Faith. ${ }^{36}$ Indeed, in this sheet Cranach translates the justification theology into visual terms that he might well have created in direct consultation with

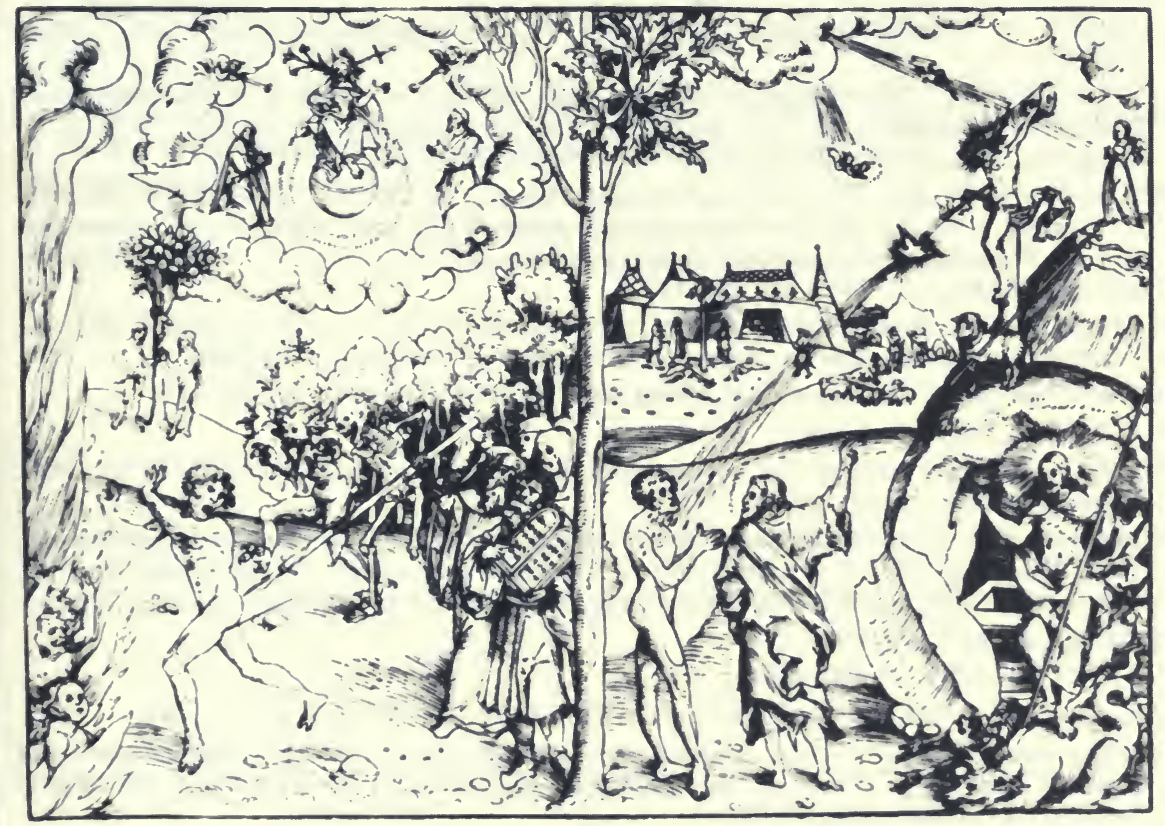

Fig. 2 L. Cranach the elder, The Justification of the Sinner before the Law by the Grace of God and Faith, woodcut, ca. 1530, Weimar, Schlossmuseum 
Luther, who at exactly that same time was preparing the Large Catechism. Support for this conjecture comes from the biblical texts appended to another printing of the same woodcut (London, British Museum) and to some painted panels. These texts are precisely those passages from Paul and John on which the justification theology is based. The bloodstream certainly alludes to Luther's interpretation of the Sacrament in the controversy with Zwingli.

Containing hieroglyphically and in a nutshell, as it were, the essence of Luther's Redemption teachings, the little woodcut is indeed a tröstlich pictura and the Reformer himself appears to be the image-maker. McGill University

Notes

Abbreviations.

WA - D. Martin Luthers Werke. Kritische Gesamtausgabe (Weimar, 1833-)

$L W$ - American Edition of Luther's Works (Philadelphia and St. Louis, 1955-)

1 Charles D.Cuttler, Northern Painting (New York, 1968), p. 415;Georg Dehio, Kunsthistorische Aufsätze (Berlin-München, 1914), pp. 147-196.

2 Herbert von Hintzenstern, Lucas Cranach d.A., Altarbilder aus der Reformationszeit (Berlin, 1972), p. 17.

3 Erwin Panofsky, "Comments on Art and Reformation" in Symbols in Transformation, Exhibition Catalogue, The Art Museum, Princeton University (Princeton, 1969), p. 9; Margarete Stirm, Die Bilderfrage in der Reformation (Gütersloh, 1977), p. 127.

4 Hans K. von Haebler, Das Bild in der evangelischen Kirche (Berlin, 1957); RDK II, col. 570 571, Stirm, p. 87. Excellent documentation is provided by Carl C. Christensen, "Iconoclasm and the Preservation of Ecclesiastical Art in Reformation Nuernberg" in Archiv für Reform. ationsgeschichte LXI, 1970, pp. 205-221.

5 Arnold Hauser, Social History of Art (London, 1962), II, p. 113; Alexander Rüstow, "Lutherana tragoedia artis" in Schweizer Monatshefte 39 (1959), pp. 891-906.

6 Erwin Panofsky, "Erasmus and the Visual Arts" in JWCI 32 (1969), pp. 207-211.

7 WA 18, 83, translation mine.

8 For a comparative discussion of both men see Robert H. Murray, Erasmus and Luther: Their Attitude to Toleration (London, $1972^{2}$ ).

9 Huldrych Zwinglis sämtliche Werke (Berlin-Zürich, 1905-), III; Hans Frh. von Campenhausen, "Die Bilderfrage in der Reformation" in Tradition und Leben, Aufsätze und Vorträge (Tübingen, 1960), pp. 361-407; Oskar Farner, Huldreich Zwingli (Hamden, Conn.), 1954.

10 Zwingli, Werke 8, 194-195.

$11 L W 40,63-71$; WA 15, 391-397.

12 Receiving Both Kinds in the Sacrament (1522), LW 36, 259-260; WA 10, 2, 11-41.

13 For a recent account of the situation see James S. Preus, Carlstadt's Ordinaciones and Luther's Liberty: A Study of the Wittenberg Movement, 1521-22, Harvard Theological Studies XXVI (Cambridge, 1976).

$14 L W 51,75-100 ; W A 10,3 ; L W 40,73-223 ; W A 18,62-125$.

$15 W A, 1-398-400$, WA $2,36,137-38$. 
16 WA, 10, 3, 31 (Invocavitpredigten), WA 10, 2, 34 (Von beiderlei Gestalt).

17 LW 51, 84; WA 10, 31, 31-32 (Eight Sermons).

18 Fedja Anzelewsky, Albrecht Dürer, Das malerische Werk (Berlin, 1971) pp. 133-137.

19 Christian Rogge, Luther und die Kirchenbilder seiner Zeit (Leipzig, 1912), p. 15. This questionable account of Luther's role in the image question was challenged by Friedrich Buchholz, Protestantismus und Kunst im 16. Jahrhundert (Leipzig, 1928).

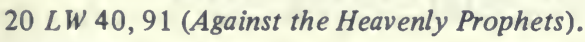

$21 L W, 51,85-86$.

22 D. Martin Luthers Werke, Briefwechsel (Weimar, 1930-) 2. 514.

$23 \mathrm{LW} 40,84$. Very similar thoughts are expressed by the rather radical Franz Von Sickingen: Martin Warnke, Bildersturm (München, 1973), p. 73.

24 LW 37, 151 and passim (Confession concerning Christ's Supper, 1528).

25 Buchholz, p. 6.

26 Hans Preuss, Martin Luther der Künstler (Gütersloh, 1931), pp. 20-25, 43: Craig Harbison in Symbols in Transformation, p. 26.

27 Heinrich Bornkamm, Luther, Gestalt und Wirkungen (Gütersloh, 1975), p. 46.

28 LW 40, 99-100 (Against the Heavenly Prophets), Italics mine.

29 Quoted, in my translation, from Walt Tappolet, Das Marienlob der Reformatoren (Tübingen, 1962), p. 149.

$30 W A 6,338 ; W A 37,63 ; W A 47,386 ; W A 40,74$ (Sermons).

$31 L W 41,323$.

32 Christine O. Kibish, "Lucas Cranach's Christ Blessing the Children - a Problem of Lutheran Iconography" in Art Bulletin 37 (1955), pp. 196-203.

33 Werner Schade, Die Malerfamilie Cranach (Dresden, 1974), chapter on "Protestantische Bildaufgaben".

34 Oskar Thulin, Cranach-Altäre der Reformation (Berlin, 1955), p. 132.

35 Dieter-Koepplin and Tilman Falk, Lukas Cranach (Basel-Stuttgart, 1976), II, p. 505-509. The soteriological aspect appears less clearly in two painted versions of the same theme in Gotha and Weimar. For reproductions see Hintzenstern, pp. 91, 93.

36 Koepplin and Falk, p. 505. 